notion that we may be not only in the late age of print, but also in the late age of text. Unfortunately, his arguments for the continuing importance of text sound a lot like those of the supporters of the textual canon and do not take into account important changes in our society. Thanks to television, there are already many people for whom text is not a part of daily life. Computer imaging, voice recognition, virtual reality, and ease of access to them through networks seem likely to accelerate that trend. If you read Writing Space (and you should), abandon linear argument and read it as a source of ideas, a book that will pull out your associations with text and give you associations that you can use in your work and further reading. You'll get mad occasionally, you may reject some of the ideas, but there are so many ideas in here that some of them are bound to change the way you see your Post-It Notes, a page of this journal, and those lines scrolling past on your terminal.-James Campbell, University of Virginia, Charlottesville.

\section{Scholarly Communication and Serial}

Prices: Proceedings of a Conference Sponsored by the Standing Conference of National and University Libraries and the British Library Research and Development Board, 11-13 June 1990.

Ed. by Karen Brookfield. London: Bowker-Saur, 1991. 155p. acid-free, \$45 (ISBN 0-86291-478-7).

As the subtitle indicates, this book consists of thirteen papers and summaries of subsequent discussions presented at a June 1990 conference in Great Britain. In the keynote address, Jack Meadows, chief librarian at Loughborough University, provides an overview of the groups involved in the production and use of serials as well as the factors to be considered in evaluating the current role of serials. His focus is entirely upon scientific, technical, and medical (STM) serials, and though some of the other authors do not mention this specifically, in fact the entire conference is concerned with the STM situation. Meadows does not point out all the motivations for scientists to publish papers, missing the crucial one of creating a paper record of research for promotion and to support grant applications. Similarly, in the discussion of the STM community (labeled "authors and readers"), he does not address two important characteristics, the increasing size of the population of scientists performing and reporting research, and the tendency for much research to be reported in small articles rather than in extended ones, the so-called "salami slicing" of scientific reporting.

Margaret Boden of the University of Sussex outlines in "Appraisal of Research" the function of peer review and some related issues of current significance to the research community as well as to librarians. Once again, however, some important points are not mentioned. She does not cite the work of Stephen Cole on the sociology of peer review in the sciences and social sciences or his key notions of "core knowledge" and "research frontier knowledge"; she refers only obliquely to impact measurements based on citation studies and the import/export of references as developed by Eugene Garfield.

Duane Webster attended in his role as executive director of the Association of Research Libraries and presented two excellent papers. The first, "The Economics of Journal Publishing: The Librarian's View," provides, uniquely in this conference, the conceptual framework as well as the supporting statistics for the fiscal dilemma confronting libraries as STM journal costs continue to exceed both the general inflation rates of the publishing industry and the ability of research library budgets to support subscriptions in the breadth and depth once thought desirable. This paper also describes one ARL initiative for coping with the crisis, the foundation of the ARL Office of Scientific and Academic Publishing. Webster's other paper, "A Perspective on the Politics of Change from the United States," argues for substantial alterations in the modes of distributing scientific and scholarly information through the electronic telecommunication networks already present and in development. In essence, he states the 
case for funding and development of the U.S. National Research and Education Network (NREN) as well as for more effective and extensive exploitation of coordinated collection development and services. The sole quibble this reviewer has with Webster's exposition is his inaccurate depiction of the debate between the proponents of local ownership and those who predict a rosy future based on the so-called paradigm of access. There may be some political reasons for this construction.

Gordon Graham's paper on the publisher's perspective on the economics of journal publishing is a gentlemanly review of the recent history of the situation. Although he attends to the important relationship between publishers and librarians, he passes lightly over the possibility of altering the expectations of the scholarly community, which is ultimately the consumer as well as the supplier of texts.

Two papers on scholarly communication in the sciences, one by Anthony Pearce about physics and another by Anthony J. Turner on biochemistry, present discipline-based views and describe the influence of the learned societies on the present crisis.

In "The Future of Scholarly Communication" Colin Campbell, then vicechancellor of the University of Nottingham, suggests a plan for regional coordinated collection development and advocates more experimentation with information technology.

Cliff McKnight and Lynne Brindley consider the electronic journal and the electronic library respectively. McKnight presents some experiences in applying mainframe computer resources to a journalpublishing venture, the BLEND project, and a hypertext electronic journal based on a CD-ROM workstation, the Project Quartet. A useful feature of McKnight's paper is his presentation of some schematic models of information delivery systems. Brindley's paper rehearses the advances which suggest to her the possibilities for a true electronic library, and in the conclusion to her excellent brief she offers seven assertions which, taken together, describe the path to further developments.
Bernard Naylor's paper, "The Politics of Change in the United Kingdom," examines the matter of "scholarly esteem" and presents several models for understanding the current situation, if not the future.

The concluding panel discussion identifies three main themes arising in the conference (escalating serials prices, technological alternatives, pressures to publish), problems of traditional serials, alternatives to traditional serials, and presents observations on the possibilities of reducing published output.

A program for action is outlined featuring four steps subsequently undertaken by various groups concerned with the problem on both sides of the Atlantic. These steps are: creating an experimental electronic journal; lobbying for change in the appraisal of research; continuing the development of a technological infrastructure suitable for communicating scientific and scholarly reports; and studying how scholars find and use information, especially with regard to serials.

Despite the minor shortcomings of many of the papers, this is a valuable résumé of the crisis in the system of scholarly communication via serials. Although there are a few obvious differences between the British and American environments, the relevance of these discussions is apparent to the global research library community. Given that Bowker-Saur is merely reporting the results of a conference funded by others, the price of the volume is unwarranted. Perhaps in the future, alternate modes of distributing the proceedings of meetings as obviously fruitful and important as this one could be managed.-Michael A. Keller, Yale University, New Haven, Connecticut.

Clotfelter, Charles T., Ronald G. Ehrenberg, Malcolm Getz, and John J. Siegfried. Economic Challenges in Higher Education. Chicago: Univ. of Chicago Pr., 1991. (A National Bureau of Economic Research Monograph.) 422 p. acid-free, $\$ 39.95$ (ISBN 0-226-11050-8). LC 9123330.

This book consists of three long economics essays on student demand for 